\title{
Seasonal variation of ice melting on varying layers of debris of Lirung Glacier, Langtang Valley, Nepal
}

\author{
MOHAN B. CHAND ${ }^{1}$, RIJAN B. KAYASTHA ${ }^{1}$, ACHUT PARAJULI ${ }^{1} \&$ \\ PRADEEP K. MOOL ${ }^{2}$ \\ 1 Himalayan Cryosphere, Climate and Disaster Research Center, Kathmandu University, Dhulikhel, Nepal \\ mohanchand06@gmail.com \\ 2 International Centre for Integrated Mountain Development, Lalitpur, Nepal
}

\begin{abstract}
Glaciers in the Himalayan region are often covered by extensive debris cover in ablation areas, hence it is essential to assess the effect of debris on glacier ice melt. Seasonal melting of ice beneath different thicknesses of debris on Lirung Glacier in Langtang Valley, Nepal, was studied during three seasons of 2013-14. The melting rates of ice under $5 \mathrm{~cm}$ debris thickness are $3.52,0.09$, and $0.85 \mathrm{~cm} \mathrm{~d}^{-1}$ during the monsoon, winter and pre-monsoon season, respectively. Maximum melting is observed in dirty ice $(0.3 \mathrm{~cm}$ debris thickness) and the rate decreases with the increase of debris thickness. The energy balance calculations on dirty ice and at $40 \mathrm{~cm}$ debris thickness show that the main energy source of ablation is net radiation. The major finding from this study is that the maximum melting occurs during the monsoon season than rest of the seasons.
\end{abstract}

Key words Himalayas; ice melting; energy balance; debris thickness

\section{INTRODUCTION}

The Himalayan glaciers are sources of water for South Asian region. Water from glaciers has significant potential for hydro-electricity generation, irrigation, drinking purposes etc. It is important to predict the long-term availability of water resources through the response of glaciers to changing climate. Himalayan and Trans-Himalayan glaciers are characterized by the presence of debris in the ablation portion of the glacier (Fujii and Higuchi, 1997). Melting of ice beneath debris cover results in the expansion of glacier lakes and formation of large supra-glacial lakes and hence increases the risk of glacial lake outburst floods. In general, the thickness of debris ranges from a few millimetres to more than metres. Melting is retarded where debris thickness exceeds a threshold of approximately $2 \mathrm{~cm}$ (Østrem, 1959; Loomis, 1970; Fujii, 1977; Mattson et al., 1993). Debris cover ranging from 0 to $5 \mathrm{~cm}$ shows that ice ablation is enhanced to a maximum at $0.3 \mathrm{~cm}$ but debris thickness of more than $5 \mathrm{~cm}$ retards ablation (Kayastha, et al., 2000). Debris covered glaciers have lost significant mass in recent decades despite their debris cover (Bolch, et al., 2008; Bolch, et al., 2011; Kääb, et al., 2012). Similarly, several researchers have found the effect of supraglacial debris on glacier melt using surface energy balance models with surface temperature and meteorological variables (Nakawo and Young, 1982; Kayastha et al., 2000; Tekeuchi, et al., 2000; Conway and Rasmussen, 2000; Haidong, et al., 2006; Nicholson and Benn, 2006; Reid and Brock, 2010; Reznichenko, et al., 2010). However, we still lack proper understanding of the processes beneath highly heterogeneous debris cover, as in the Nepalese Himalayas. This paper presents the results of energy balance model calculations on Lirung Glacier to estimate the melt rate under different debris thickness, which is then compared with the measured melt rate in different seasons of 2013 and 2014.

\section{STUDY AREA}

This study is conducted on Lirung Glacier $\left(28.422^{\circ} \mathrm{N}, 85.517^{\circ} \mathrm{E}\right)$ which lies in Langtang catchment of Langtang Valley (Fig. 1). The elevation ranges from the terminus at $4000 \mathrm{~m}$ a.m.s.l. to Mt. Langtang Lirung peak at $7234 \mathrm{~m}$ a.m.s.l. The Lirung Glacier covers about $13.51 \mathrm{~km}^{2}$, of which $1.13 \mathrm{~km}^{2}$ is ablation area. It consists of a very steep accumulation area, the ablation area covered by a thick mantle of debris $(>50 \mathrm{~cm})$ that is detached from the accumulation area, followed by a pro-glacial valley with several small ponds and one large pro-glacial pond which is disconnected from the glacier terminus. This study is focused on the ablation part of the glacier. 


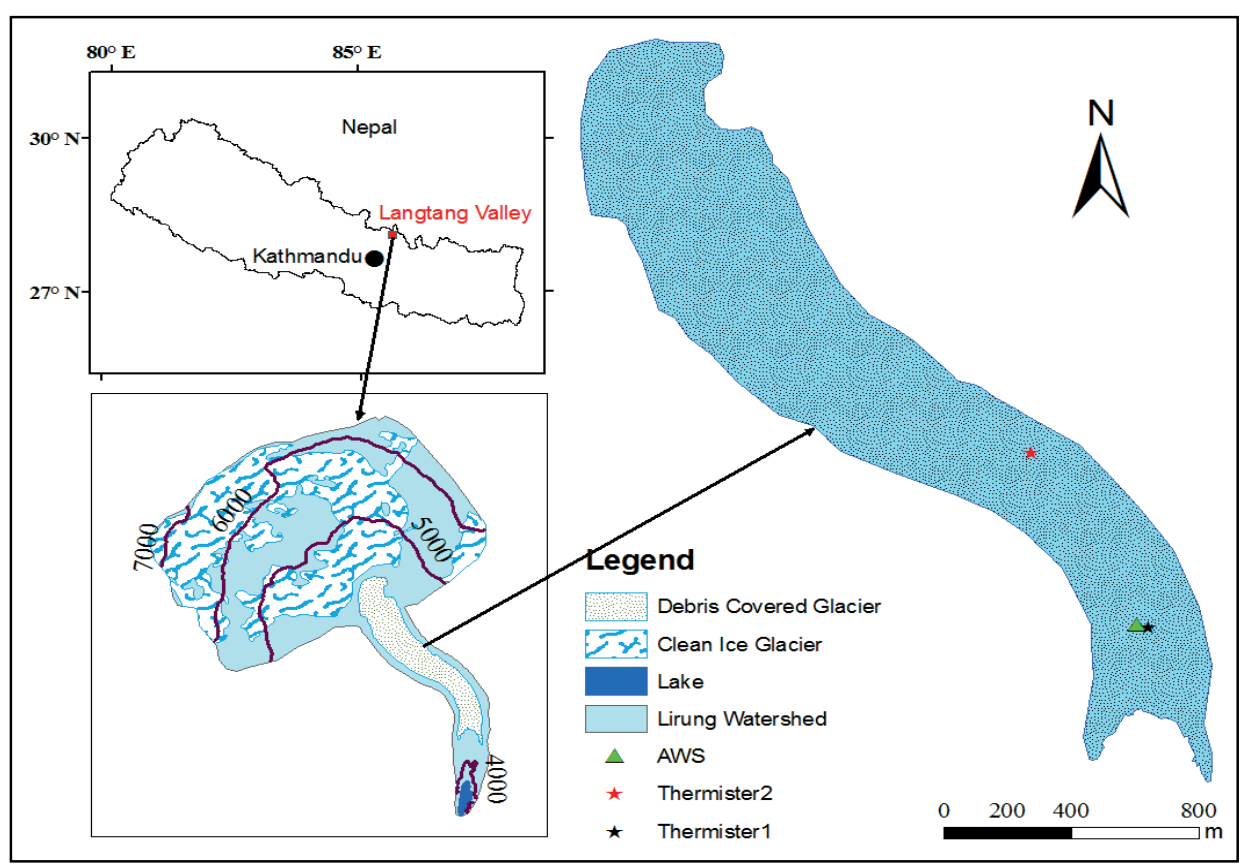

Fig. 1 Location map of study area showing location of AWS and thermistors in the glacier.

\section{DATA COLLECTION AND OBSERVATIONS}

Field measurements are carried out in 2013 and 2014 spanning three different seasons, i.e. the monsoon and winter seasons of 2013 and pre-monsoon season of 2014. The glacio-meteorological experimental set-up consists of an automatic weather station (AWS), two sets of thermistors, ablation stakes and an instrument to measure the albedo of the debris. Ice ablation measurement is carried out daily using bamboo stakes in the glacier under the different thickness of debris, ranging from 0.3 to $42 \mathrm{~cm}$. In total, seven ablation stakes in the monsoon and winter season and 13 stakes in the pre-monsoon season are installed.

\section{METEOROLOGICAL CONDITIONS}

A Davis AWS is installed (at $28.232^{\circ} \mathrm{N}, 85.559^{\circ} \mathrm{E}$, and elevation $4093 \mathrm{~m}$ a.m.s.l.) to observe the meteorological parameters of the glacier in three seasons. The meteorological parameters including air temperature $\left({ }^{\circ} \mathrm{C}\right)$, relative humidity $(\%)$, solar radiation $\left(\mathrm{W} \mathrm{m}^{-2}\right)$, and daily rainfall $(\mathrm{mm})$ are recorded at 1 metre above the debris surface, and wind speed $\left(\mathrm{m} \mathrm{s}^{-1}\right)$ and direction are measured at the height of 2 metres. All the meteorological parameters are recorded every 5 minutes in each season, and the hourly variation of meteorological parameters is used for the calculation of the energy balance components. The mean air temperature, humidity, solar radiation and wind speed are given in Table 1.

Table 1 Mean value of air temperature, relative humidity, solar radiation and wind speed during monsoon, winter and pre-monsoon period.

\begin{tabular}{lllll}
\hline Seasons & Air temperature $\left({ }^{\circ} \mathrm{C}\right)$ & Humidity $(\%)$ & Solar Radiation $\left(\mathrm{W} \mathrm{m}^{-2)}\right.$ & Wind speed $\left(\mathrm{m} \mathrm{s}^{-1}\right)$ \\
\hline Monsoon & 7.86 & 86.71 & 185.4 & 0.12 \\
Winter & 0.005 & 37.47 & 169.45 & 0.27 \\
Pre-monsoon & 1.28 & 54.02 & 235.78 & 0.34 \\
\hline
\end{tabular}

Presence of cloud cover during the monsoon decreases the incoming solar radiation. The air temperature is compared with the Kyangjing meteorological station at $3862 \mathrm{~m}$ a.m.s.l., and the lapse rate found to be 0.13 and $0.09^{\circ} \mathrm{C}$ per $100 \mathrm{~m}$ during the monsoon and winter seasons, respectively. The daytime temperature of the debris-covered glacier is higher than at Kyangjing and lower at 
night-time. This is due to stored heat release by the debris in daytime. Several precipitation events occurred during the monsoon season, none during winter and a couple in the pre-monsoon season. The total precipitation during the monsoon season is $22.07 \mathrm{~mm}$ in the form of rain and $18.70 \mathrm{~mm}$ during the pre-monsoon season in the form of snow. Cloud cover is estimated as $8 / 10,0 / 10$, and $7 / 10$ during the monsoon, winter and pre-monsoon season, respectively.

\section{ABLATION BENEATH DEBRIS USING ENERGY BALANCE EQUATION}

The energy balance equation on top of a debris layer can be expressed as:

$$
\mathrm{Q}_{\mathrm{C}}=\mathrm{Q}_{\mathrm{R}}+\mathrm{Q}_{\mathrm{H}}+\mathrm{Q}_{\mathrm{E}}
$$

where, $\mathrm{Q}_{\mathrm{C}}, \mathrm{Q}_{\mathrm{R}}, \mathrm{Q}_{\mathrm{H}}$ and $\mathrm{Q}_{\mathrm{E}}$ are conductive heat flux through the debris, net radiation flux, sensible heat flux, and latent heat flux. Heat flux due to precipitation is neglected. The net radiation flux is the sum of net shortwave $\left(\mathrm{K}^{*}\right)$ and longwave radiation $\left(\mathrm{L}^{*}\right)$ fluxes.

\section{Solar shortwave radiation}

$$
K^{*}=\mathrm{S}_{\downarrow}\left(1-\alpha_{\mathrm{d}}\right)
$$

where $\alpha_{d}$ is the debris albedo.

\section{Longwave radiation}

The downward longwave radiation under clear sky $L_{\downarrow}$ is calculated from the equation by Kuz'min (1961):

$$
\mathrm{L}_{\downarrow}=\sigma\left(\mathrm{T}_{\mathrm{a}}+273\right)^{4}\left(0.62+0.005 \sqrt{\mathrm{e}_{\mathrm{a}}}\right.
$$

where, $\sigma$ is the Stephan-Boltzmann constant $\left(5.67 \times 10^{-8} \mathrm{~W} \mathrm{~m}^{-1} \mathrm{~K}^{-4}\right), \mathrm{T}_{\mathrm{a}}$ is air temperature ${ }^{\circ} \mathrm{C}$, and $\mathrm{e}_{\mathrm{a}}$ is vapour pressure of the air $(\mathrm{Pa})$.

$$
\mathrm{L}_{\uparrow}=\sigma\left(\mathrm{T}_{\mathrm{s}}+273\right)^{4}
$$

$\mathrm{T}_{\mathrm{s}}$ is the surface temperature in Kelvin. The net longwave radiation $\left(\mathrm{L}^{*}\right)$ under a cloudy sky is given by (Oke, 1987):

$$
\mathrm{L}^{*}=\left(\mathrm{L}_{\downarrow}-\mathrm{L}_{\uparrow}\right)\left(1-0.96 c^{2}\right)
$$

\section{Turbulent heat fluxes}

The convective or turbulent heat fluxes $\mathrm{Q}_{\mathrm{H}}$ and $\mathrm{Q}_{\mathrm{E}}$ are estimated using the bulk aerodynamic method:

$$
\begin{aligned}
& \mathrm{Q}_{\mathrm{H}}=\beta \mathrm{u}\left(\mathrm{T}_{\mathrm{a}}-\mathrm{T}_{\mathrm{s}}\right) \\
& \mathrm{Q}_{\mathrm{E}}=\beta \mathrm{u} \mathrm{L}_{\mathrm{e}} \frac{0.622}{\mathrm{Pc}_{\mathrm{P}}}\left(\mathrm{e}_{\mathrm{a}}-\mathrm{e}_{\mathrm{s}}\right)
\end{aligned}
$$

where, $\beta$ is the bulk transfer coefficient $\left(4.9 \mathrm{~J} \mathrm{~m}^{-3} \mathrm{~K}^{-1}\right.$, Naruse et al., 1970); $\mathrm{u}$ is wind speed $\left(\mathrm{m} \mathrm{s}^{-1}\right)$; $\mathrm{L}_{\mathrm{e}}$ is the latent heat of evaporation $\left(2.5 \times 10^{6} \mathrm{~J} \mathrm{~kg}^{-1}\right)$; $\mathrm{P}$ is atmospheric pressure $(\mathrm{hPa})$; $\mathrm{c}_{\mathrm{P}}$ is the specific heat of air at constant pressure $\left(1005 \mathrm{~J} \mathrm{~kg}^{-10} \mathrm{C}^{-1}\right)$; $\mathrm{e}_{\mathrm{a}}$ is vapour pressure of the air $(\mathrm{hPa}) ; \mathrm{e}_{\mathrm{s}}$ is saturation vapour pressure at the surface $(\mathrm{hPa})$.

A linear variation of temperature is assumed in the debris layer (Kayastha et al., 2000):

$$
\mathrm{Q}_{\mathrm{C}}=\frac{\mathrm{T}_{\mathrm{s}}}{\mathrm{R}}
$$

where, Ts is the debris surface temperature relative to melting $\left(0^{\circ} \mathrm{C}\right)$ and $\mathrm{R}\left(\mathrm{m}^{2 \circ} \mathrm{Cw}^{-1}\right)$ is the effective thermal resistance of the debris layer.

The heat used for ice ablation $\mathrm{Q}_{\mathrm{c}}$ is calculated as:

$$
\mathrm{Q}_{\mathrm{c}}=\mathrm{L}_{\mathrm{f}} \rho_{\mathrm{i}} \mathrm{r}
$$

where, $\mathrm{L}_{\mathrm{f}}$ is the latent heat of ice $\left(334 \times 10^{3} \mathrm{~J} \mathrm{~kg}^{-1}\right), \rho_{\mathrm{i}}$ is density of the ice $\left(900 \mathrm{~kg} \mathrm{~m}^{-3}\right)$ and $\mathrm{r}$ is ablation rate of ice at a specific debris thickness $\left(\mathrm{m} \mathrm{s}^{-1}\right)$. 


\section{RESULTS AND DISCUSSION}

\section{Ice ablation}

The measured mean daily ablation rates under $5 \mathrm{~cm}$ debris thickness are $3.52,0.09$ and 0.85 $\mathrm{cm} \mathrm{d}^{-1}$, and under $20 \mathrm{~cm}, 1.85,0.02$ and $0.29 \mathrm{~cm} \mathrm{~d}^{-1}$, during the monsoon, winter and pre-monsoon seasons, respectively. The measured mean daily ablation rates for debris thickness of 0.3 to $40 \mathrm{~cm}$ are 2.52, 0.07, and $0.99 \mathrm{~cm} \mathrm{~d}^{-1}$, during the monsoon, winter, and pre-monsoon, respectively (Fig. 2). The largest mean daily ablation rate $\left(6.2 \mathrm{~cm} \mathrm{~d}^{-1}\right)$ occurred in the monsoon season at dirty ice (debris thickness is considered as $0.3 \mathrm{~cm}$ ) and decreased with the increase of debris thickness, which is similar to the finding of Østrem (1959) and many other scientists. Kayastha et al. (2000) found ablation rates of $6.4 \mathrm{~cm} \mathrm{~d}^{-1}$ at Khumbu Glacier just before the monsoon season under $0.3 \mathrm{~cm}$ of debris, which is equivalent to ablation on dirty ice during the monsoon season in the present study. These values show that the largest mean daily ablation is found during monsoon season and lowest during winter season.

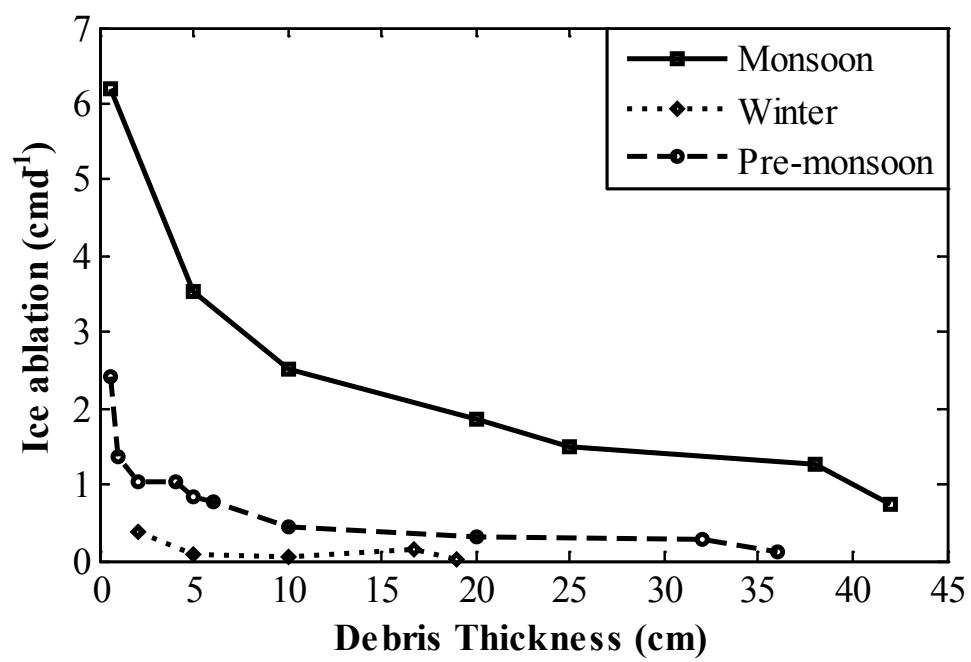

Fig. 2 Daily ablation rate during the monsoon (line with rectangles), winter (dotted line with rhombi) and pre-monsoon season (dashed line with circles).

The above equations of energy balance model are used to estimate the energy available at the debris surface. The ice melt calculated using the energy balance model is compared with measured melt rates in the winter and pre-monsoon seasons. The different components of energy balance at different times of the day are shown in Fig. 3. Surface temperature of dirty ice is always assumed to be zero. The main source of energy is net shortwave radiation, which contributes about $100 \%$ under debris of $40 \mathrm{~cm}$ thickness in both seasons. Similarly, it accounts for $97 \%$ during winter and $96 \%$ during the pre-monsoon season in dirty ice. There is no contribution by sensible heat flux under the $40 \mathrm{~cm}$ debris layer in either season due to the average surface temperature being higher than the air temperature and evaporation from the wet debris (Kayastha et al., 2000). The higher average surface temperature is due to the absorbance of solar radiation by the debris due to the lower albedo (Tekeuchi et al., 2000; Nicholson and Benn, 2006). It makes a small contribution to melting of dirty ice (3\% in winter season and $4 \%$ in pre-monsoon season). The net shortwave radiation is almost the similar in each day during winter because there are no rainfall events or occurrence of cloud cover. However, in the pre-monsoon season, net shortwave radiation is observed to fluctuate daily and is low on 12 and 14 April 2014. This is due to the increased albedo from snowfall on the debris on those days. The net shortwave radiation is about $35 \%$ higher in the pre-monsoon season than winter.

Figure 4 shows the calculated and observed variations of mean ice ablation rate during the winter and pre-monsoon season for dirty ice and under different debris thicknesses. The calculated 
ablation is almost similar to observed ablation with some deviation at smaller debris thickness, but the calculated melt is always higher than the observed melt. The calculated melt rate in winter under $5 \mathrm{~cm}$ is greater than the observed melt rate by $0.65 \mathrm{~cm} \mathrm{~d}^{-1}$. Similarly, in the pre-monsoon season the calculated melt rate is greater than observed by $0.21 \mathrm{~cm} \mathrm{~d}^{-1}$ under $10 \mathrm{~cm}$ debris thickness. This is due to the use of surface temperature measured at the $40 \mathrm{~cm}$ debris layer for all debris thicknesses. In the winter season, the calculated ablation rate is always higher than the observed ablation. There is no variation of melting under debris thicknesses of 20 and $35 \mathrm{~cm}$ during the pre-monsoon season.
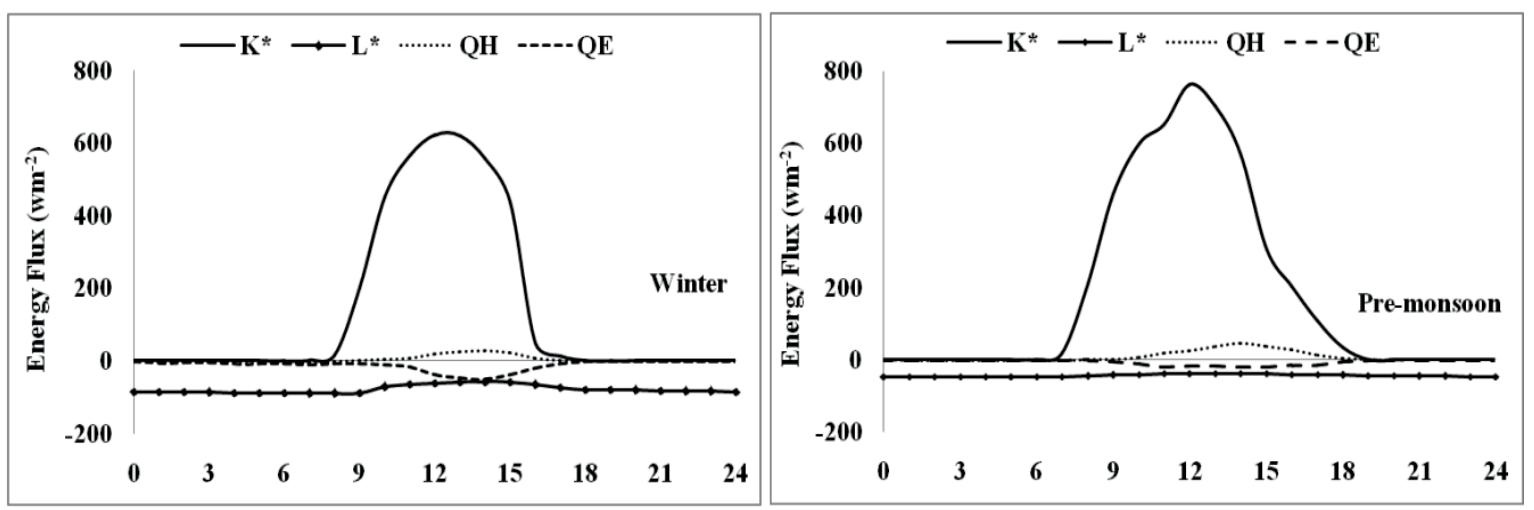

Fig. 3 Mean daily cycles of calculated surface heat fluxes for winter and the pre-monsoon season at the AWS site.
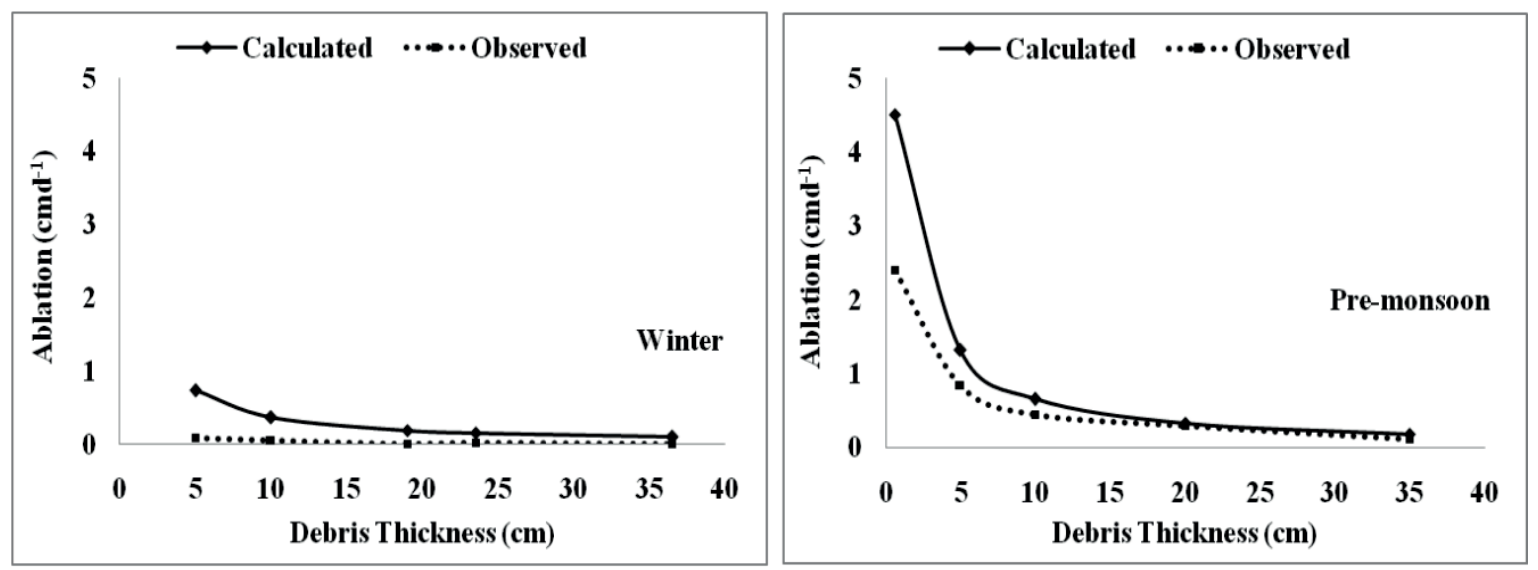

Fig. 4 Comparison of observed and calculated daily ice ablation during the winter season, and during the pre-monsoon season; square and lines with dots indicate the observed and calculated ice ablation, respectively.

\section{CONCLUSIONS}

The model applied in this study is helpful for calculating the ice melt beneath different debris thicknesses from meteorological parameters. Lack of surface temperature data for all the debris thicknesses is the limitation of model. However, the model performs well and the simulation pattern is good with almost similar melt rates under greater debris thicknesses during the premonsoon season. Observed ablation of ice is highest $\left(3.52 \mathrm{~cm} \mathrm{~d}^{-1}\right)$ during the monsoon season and lowest $\left(0.09 \mathrm{~cm} \mathrm{~d}^{-1}\right)$ during winter, while in the pre-monsoon season the ablation rate $\left(0.85 \mathrm{~cm} \mathrm{~d}^{-1}\right)$ lies between the monsoon and winter season under debris thickness of $5 \mathrm{~cm}$. The largest mean daily ablation rate $\left(6.2 \mathrm{~cm} \mathrm{~d}^{-1}\right)$ is occurred in monsoon season at a debris thickness of 0.3 and the ablation rate decreased as debris thickness increased. The calculated melt obtained from the energy balance calculation is higher than the observed melt by $0.31 \mathrm{~cm} \mathrm{~d}^{-1}$ in winter and $0.21 \mathrm{~cm} \mathrm{~d}^{-1}$ in the pre-monsoon season under $10 \mathrm{~cm}$ debris thickness. The model presented the melt rates for winter 
and pre-monsoon season. Melt rates for other seasons should be calculated from the model at different thicknesses of debris layer. Hence, this type of modelling is very useful for the Himalayan region as it allows us to know the melting pattern in highly heterogeneous debris, where the ablation part of most glaciers are debris covered. The model also helps in assessing future water availability with a minimal data range.

Acknowledgements We are very grateful to the $\mathrm{HKH}$ Cryosphere Monitoring Project implemented by the International Centre for Integrated Mountain Development (ICIMOD) and supported by the Norwegian Ministry of Foreign Affairs. We also like the thank the project partners for their help in carrying out this study, including the Himalayan Cryosphere, Climate and Disaster Research Center, Kathmandu University; Central Department of Hydrology and Meteorology, Tribhuvan University; Department of Hydrology and Meteorology, Government of Nepal; and Water and Energy Commission Secretariat, Government of Nepal; and Department of National Park and Wildlife Conservation, Government of Nepal. We would like to express thanks to Lakshman Lama, Sanjaya Gurung, Rakesh Kayastha and Roshan Dahal for their assistance in data analysis and field works. We express our gratitude to Himal Venture Treks and Exp. P. Ltd., Kathmandu and local people of Langtang Valley for the logistic support during field works.

\section{REFERENCES}

Bolch, T., et al. (2008) Planimetric and volumetric glacier changes in the Khumbu Himal, Nepal, since 1962 using Corona, Landsat TM and ASTER data. J. Glaciol. 54(187), 592-600.

Bolch, T., Pieczonka, T. and Benn, D. (2011) Multi-decadal mass loss of glaciers in the Everest area (Nepal Himalaya) derived from stereo imagery. Cryosphere 5(2), 349-358.

Conway, H. and Rasmussen, L. A. (2000) Summer Temperature profiles within supraglacial debris on Khumbu Glacier, Nepal. Debris-Covered Glaciers (ed. by Nakawo, M. et al.), 89-97. IAHS Publ. 264. IAHS Press, Wallingford, UK.

Fujii, Y. (1977) Field experiment on glacier ablation under a layer of debris cover. J. Japan Soc. Snow Ice (Spec. Iss.), 20-21.

Fujii, Y. and Higuchi, K. (1997) Statistical analysis of the forms of glaciers in Khumbu region. J. Japan. Soc. Snow Ice 39, 7-14.

Haidong, H., Yonging, D. and Shiyin, L. (2006) A simple model to estimate ice ablation under a thick debris layer. J. Glaciol. $52(179), 528-536$.

Kääb, A., et al. (2012) Contrasting patterns of early twenty-first-century glacier mass change in the Himalayas. Nature 488 (7412), 495-598.

Kayastha, R. B., et al. (2000) Practical prediction of ice melting beneath various thickness of debris cover on Khumbu Glacier, Nepal using a positive degree-day factor. Debris-Covered Glaciers (ed. by Nakawo, M. et al.), 71-81. IAHS Publ. 264. IAHS Press, Wallingford, UK.

Kuz'min, P. P. (1961) Protess Tayabiya Shezhnogo Pokarova (Melting of snow cover). Gidrometerol. Izd. Leningrad (English Translation TT71-50095, Israel Program Sci. Jerusalem, 1972.

Loomis, S. R. (1970) Morphology and ablation processes on glacier ice. (pp. 2, 88-92). Assoc. Am. Georgr. Proc.

Mattson, L. E., Gardner, J.S. and Young, G.J. (1993) Ablation on debris covered glaciers: an example from the Rakhiot Glacier, Punjab Himalaya. Snow and Glacier Hydrology (ed. by Young, G.J.), 289-296. IAHS Publ. 218. IAHS Press, Wallingford, UK.

Mihalcea, C., et al. (2006) Ice ablation and meteorological conditions on the debris covered area of Baltoro Glacier (Karakoram, Pakistan). Ann. Glaciol. 43, 292-300.

Nakawo, M. and Young, G.J. (1982) Estimate of glacier ablation under a debris layer from surface temperature and meteorological variables. J. Glaciol. 28 (98), 29-34.

Nicholson, L. and Benn, D. I. (2006) Calculating ice melt beneath a debris layer using meteorological data. J. Glaciol. 52(178), 463-470.

Oke, T. R. (1987) Boundary Layer Climates, second edn. Methuen, London and New York.

Østrem, G. (1959) Ice melting under a thin layer of moraine and the existence of ice cores in moraine ridges. Geogr. Ann. 41(4), 228-230.

Reid, T. D. and Brock, B.W. (2010) Energy-balance model for debris-covered glaciers including heat conduction through the debris layer. J. Glaciol, 56(199), 903-917.

Reznichenko, N., et al. (2010) Effect of debris on ice-surface melting rates: an experimental study. J. Glaciol. 56(197), 384-394.

Tekeuchi, Y., Kayastha, R.B. and Nakawo, M. (2000) Characteristics of ablation and heat balance in debris-free and debris covered area on Khumbu Glacier, Nepal Himalayas, in the pre-monsoon season. Debris-Covered Glaciers (ed. by Nakawo, M. et al.), 53-61. IAHS Publ. 264. IAHS Press, Wallingford, UK. 